\title{
The $\alpha$ subunit of $E$. coli RNA polymerase activates RNA binding by NusA
}

\author{
Thien-Fah Mah, ${ }^{1}$ Konstantin Kuznedelov, ${ }^{2}$ Arcady Mushegian, ${ }^{2,3}$ Konstantin Severinov, ${ }^{2}$ \\ and Jack Greenblatt ${ }^{1,4}$ \\ ${ }^{1}$ Banting and Best Department of Medical Research and Department of Molecular and Medical Genetics, University \\ of Toronto, Toronto, Ontario M5G 1L6, Canada; ${ }^{2}$ Waksman Institute and Department of Genetics, Rutgers, The State \\ University of New Jersey, Piscataway, New Jersey 08854, USA
}

The Escherichia coli NusA protein modulates pausing, termination, and antitermination by associating with the transcribing RNA polymerase core enzyme. NusA can be covalently cross-linked to nascent RNA within a transcription complex, but does not bind RNA on its own. We have found that deletion of the 79 carboxy-terminal amino acids of the 495-amino-acid NusA protein allows NusA to bind RNA in gel mobility shift assays. The carboxy-terminal domain (CTD) of the $\alpha$ subunit of RNA polymerase, as well as the bacteriophage $\lambda N$ gene antiterminator protein, bind to carboxy-terminal regions of NusA and enable full-length NusA to bind RNA. Binding of NusA to RNA in the presence of $\alpha$ or $N$ involves an amino-terminal S1 homology region that is otherwise inactive in full-length NusA. The interaction of the $\alpha$-CTD with full-length NusA stimulates termination. $\mathbf{N}$ may prevent termination by inducing NusA to interact with $\mathbf{N}$ utilization (nut) site RNA rather than RNA near the 3' end of the nascent transcript. Sequence analysis showed that the $\alpha$-CTD contains a modified helix-hairpin-helix motif $(\mathrm{HhH})$, which is also conserved in the carboxy-terminal regions of some eubacterial NusA proteins. These HhH motifs may mediate protein-protein interactions in NusA and the $\alpha$-CTD.

[Key Words: NusA; $\alpha$ subunit; RNA-binding; HhH motifs; termination; antitermination]

Received May 30, 2000; revised version accepted September 1, 2000.

The NusA protein of Escherichia coli binds to core RNA polymerase shortly after the initiation of transcription and stimulates pausing and termination at certain sites (for review, see Richardson and Greenblatt 1996). The mechanism by which NusA influences pausing during transcription is not yet clear, but RNase protection experiments suggest that NusA may bind and stabilize the stem-loop RNA structures often associated with pause sites (Landick and Yanofsky 1987). By increasing the dwell time of RNA polymerase at such a pause site, this stabilization may serve to couple transcription and translation (Zheng and Friedman 1994). In vitro studies have shown that NusA also enhances termination of transcription at intrinsic terminators /Greenblatt et al. 1981; Grayhack and Roberts 1982; Schmidt and Chamberlin 1987; Whalen et al. 1988). These terminators also contain a GC-rich stem-loop in the nascent transcript upstream of the termination site, and it is possible that

\footnotetext{
${ }^{3}$ Present address: Akkadix Corporation, 11099 N. Torrey Pines Road, La Jolla, CA 92037, USA.

${ }^{4}$ Corresponding author.

E-MAIL jack.greenblatt@utoronto.ca; FAX (416) 9788528.

Article and publication are at www.genesdev.org/cgi/doi/10.1101/gad. 822900 .
}

NusA helps promote release of the transcript by stabilizing the RNA stem-loop and blocking its interaction with a single-stranded RNA-binding site on RNA polymerase (Artsimovich and Landick 1998). Consistent with this, the NusA in a transcription complex could be cross-linked to the nascent RNA located more than 10 nucleotides from the $3^{\prime}$ end of the transcript (Liu and Hanna 1995).

NusA binds directly to the $\alpha$ subunit of RNA polymerase (Liu et al. 1996). It can also be cross-linked to the large $\beta$ and $\beta^{\prime}$ subunits of RNA polymerase (J. Li and J. Greenblatt, unpubl.) and may be capable of binding directly to these subunits as well (Liu et al. 1996). The $\alpha$ subunit of RNA polymerase has two domains: The amino-terminal domain (NTD) is required for dimerization and for interaction with the $\beta$ and $\beta^{\prime}$ subunits of RNA polymerase, whereas the carboxy-terminal domain (CTD) is a contact surface for DNA-binding activator proteins (for review, see Ebright and Busby 1995) and possesses a minor dimerization interface (Blatter et al. 1994). The CTD of $\alpha$ also binds the UP element, a DNA element that enhances initiation of transcription at certain promoters (Ross et al. 1993; Blatter et al. 1994). Additionally, it has been suggested that a direct interaction between the $\alpha$-CTD and NusA is important for 
NusA's ability to control pausing and termination (Liu et al. 1996).

NusA influences not only pausing and termination by RNA polymerase, but also transcriptional antitermination by the bacteriophage $\lambda \mathrm{N}$ protein (Friedman 1971). Antitermination by $\mathrm{N}$ requires a cis-acting RNA element, called the nut site, which consists of two functional components, boxA and boxB (Salstrom and Szybalski 1978; de Crombrugge et al. 1979; Olson et al. 1982; Das and Wolska 1984; Horwitz et al. 1987). NusA, as well as the E. coli proteins NusB, NusE (ribosomal protein S10), NusG, RNA polymerase, and the nut site on the phage RNA, take part in multiple interactions within the $\mathrm{N}$-modified transcription complex (for review, see Friedman 1988; Greenblatt et al. 1993). The resulting highly stable ribonucleoprotein complex is capable of suppressing transcription termination over long distances and through multiple terminators (Mason et al. 1992; Mogridge et al. 1995). Within this complex, NusA interacts with the N protein (Greenblatt and Li 1981b), and both the amino- and carboxy-terminal regions of NusA interact with RNA polymerase (Mah et al. 1999).

The 107-amino-acid phage $\lambda \mathrm{N}$ protein has been dissected into an amino-terminal arginine-rich motif (amino acids 1-22), which binds as a bent $\alpha$-helix to the boxB RNA hairpin in the nut site (Legault et al. 1998), and an activating region (amino acids 23-107) also required for transcriptional antitermination (Mogridge et al. 1998). At least two portions of the activating region are important for antitermination: Amino acids 34-47 interact with NusA, and amino acids 73-107 interact with RNA polymerase. A carboxy-terminally truncated $\lambda$ N protein (amino acids 1-47), which can interact with both the nut site RNA and NusA, has partial antitermination activity: It is sufficient to reverse the enhancing effect that NusA has on the efficiency of an intrinsic terminator, but does not provide complete terminator read-through (Mogridge et al. 1998). This suggests that an interaction of $\mathrm{N}$ with NusA may reverse the effect of NusA on termination.

Sequence comparisons revealed two types of putative RNA-binding domains in NusA, an S1 homology region and tandemly duplicated $\mathrm{KH}$ homology regions (Gibson et al. 1993a,b; Bycroft et al. 1997). S1 and KH domains are both found in proteins that can associate with RNA nonspecifically (Gibson et al. 1993a,b; Bycroft et al. 1997). The S1 domain was first identified in ribosomal protein S1, which has six of them, whereas the KH domain was initially identified in the hnRNP K protein (Subramanian 1983; Siomi et al. 1993). Recent studies with other S1- and KH-domain-containing proteins and with the isolated domains themselves have suggested that these domains can be capable of sequence-specific RNA binding (Ringquist et al. 1995; Dejgaard and Leffers 1996; Dodson and Shapiro 1997).

There is evidence that NusA may interact directly with nucleotides in both the box $A$ and box $B$ components of the nut site (Olson et al. 1982; Friedman and Olson 1983; Olson et al. 1984; Mogridge et al. 1995). The effects of mutations in the S1 homology region of NusA between amino acids 136 and 240 suggest that this region is important for antitermination. The nusA1 (L183R) and nusA R199A mutations both cause temperature-sensitive $\lambda$ growth because of an inability of $\mathrm{N}$ to function at high temperature (Friedman 1971; Friedman and Baron 1974; T. Mah, Y. Zhou, N. Yu, J. Mogridge, E. Olsen, J. Greenblatt, and D. Friedman, unpubl.). Unlike wild-type NusA, both mutant proteins are unable to supershift an N-nut-site-RNA complex in a gel mobility shift experiment, even though they bind $\mathrm{N}$ directly with wild-type affinity. This suggests that both mutations cause a defect in the interaction of the S1 homology region of NusA with nut-site RNA (T. Mah, Y. Zhou, N. $\mathrm{Yu}$, J. Mogridge, E. Olsen, J. Greenblatt, and D. Friedman, unpubl.). Other experiments have shown that both an amino-terminal RNA polymerase-binding region in amino acids $1-137$ and a portion of NusA that contains the $\mathrm{S} 1$ and $\mathrm{KH}$ homology regions are essential for NusA to enhance both termination at an intrinsic terminator and antitermination by N (Mah et al. 1999).

Despite the evidence suggesting that NusA can interact with RNA, the full-length NusA protein does not cause a mobility shift of the phage $\lambda$ nut-site RNA in a gel retardation assay unless the $\mathrm{N}$ protein is also present (Mogridge et al. 1995). A direct interaction between NusA and $\mathrm{N}$ has been demonstrated (Greenblatt and Li 1981b), and it is likely that this interaction confers an RNA-binding ability on NusA. Since NusA does crosslink to RNA in a transcription complex in the absence of N (Liu and Hanna 1995), it seemed likely that an interaction of NusA with RNA polymerase might also alter the conformation of NusA so as to allow for RNA binding.

In this work, we report that the $\alpha$ subunit of E. coli RNA polymerase and the $\lambda \mathrm{N}$ protein bind to the carboxy-terminal regions of NusA, suggesting that $\alpha$ and $N$ may act in similar ways to control the binding of NusA to RNA, and that interaction of $\alpha$ with NusA promotes the association of NusA with RNA. Our results suggest that an interaction of NusA with $\alpha$ in a transcription complex would allow NusA to bind the nascent transcript and stimulate pausing and termination by RNA polymerase. This interaction appears to be inhibited by the 79 carboxy-terminal amino acids of NusA, as judged from the ability of the truncated form of NusA to bind RNA independently. Sequence analysis shows that both the $\alpha$-CTD and the NusA carboxy-terminal regulatory region contain modified versions of a helix-hairpin-helix $(\mathrm{HhH})$ motif. This motif has been found in a wide variety of DNA-binding and RNA-binding proteins, including many enzymes involved in DNA replication and repair, and is thought to mediate non-sequence-specific binding of proteins to nucleic acids. Our data may be indicative of a different kind of function for the $\mathrm{HhH}$ motifs in the $\alpha$-CTD and NusA, namely, participation in intermolecular $\alpha$-CTD-NusA complex formation and intramolecular protein-protein interactions within NusA. The $\lambda \mathrm{N}$ protein may reverse the effects of NusA on pausing and termination by causing NusA to interact with nut-site RNA rather than the RNA near the $3^{\prime}$ end of the nascent transcript. 
Mah et al.

\section{Results}

NusA binds to RNA in vitro only in the presence of the full-length RNA-polymerase $\alpha$ subunit or a fragment of $\alpha$ containing its carboxy-terminal domain

In view of the known involvement of the $\alpha$ subunit of RNA polymerase in NusA function (Liu et al. 1996), we tested whether $\alpha$ could promote RNA binding by NusA in gel mobility shift assays containing ${ }^{32} \mathrm{P}$-labeled RNA with a wild-type $\lambda$ nut site (Fig. 1). The addition of increasing amounts of $\alpha$ to a constant amount of NusA resulted in the appearance of two bands, and sometimes a weak third band, with lower mobility than the free RNA (Fig. 1A, cf. lane 1 with lanes 7-10). These bands were absent in lanes containing either NusA alone (lane 2) or the full concentration range of $\alpha$ alone (lanes 3-6), indicating that formation of a complex on the RNA required both proteins. In the converse experiment, in which the concentration of $\alpha$ was held constant and that of NusA was varied (Fig. 1B), NusA alone was not able to bind nut-site-containing RNA, even at very high concentrations (lanes 2-4), but complexes of lower mobility appeared and increased in intensity as the concentration of NusA was increased in the presence of $\alpha$ (lanes 6-8). In view of the known ability of $\alpha$ to dimerize, primarily via its amino-terminal domain (Blatter et al. 1994; Kimura et al. 1994), these complexes may represent different combinations of $\alpha$ and NusA. The apparent $K_{\mathrm{d}}$ of the interaction of NusA and $\alpha$ with the RNA is at least $100 \mu \mathrm{M}$ because only a small fraction $(2 \%-5 \%)$ of the RNA is bound when the concentrations of NusA and $\alpha$ are about $10 \mu \mathrm{M}$. It is possible that the gel mobility shift assay is overestimating the $K_{\mathrm{d}}$ if not all the molecules of NusA and $\alpha$ are active. However, such weak binding may not be surprising because NusA and $\alpha$ are both bound to RNA polymerase and therefore are both in the vicinity of each other and the nascent RNA during transcription.

Since the CTD of the RNA-polymerase $\alpha$ subunit is known to be important for NusA activity in pausing and termination (Liu et al. 1996), we tested whether the $\alpha$-CTD (amino acids 249-329) or $\alpha$-NTD (amino acids 1-235) alone could promote RNA binding by NusA (Fig. $1 \mathrm{C})$. We added full-length $\alpha, \alpha$-CTD, or $\alpha$-NTD to gel mobility shift reactions with NusA and ${ }^{32} \mathrm{P}$-labeled nutsite-containing RNA. Neither the $\alpha$ subunit nor its isolated amino- and carboxy-terminal domains alone could retard the mobility of the RNA (lanes 3-6), unlike the carboxy-terminally truncated NusA molecule containing amino acids 1-416, which is capable of direct binding to nut-site-containing RNA (lane 2; also see below). The addition of either intact $\alpha$ (lanes 7 and 8) or the $\alpha$-CTD (lanes 9 and 10) to intact NusA (amino acids 1-495) caused shifts in the mobility of the RNA. The complex formed with the $\alpha$-CTD and NusA (lanes 9 and 10) was similar, but not identical, in mobility to the more rapidly migrating complex obtained when full-length $\alpha$ was incubated with NusA (lanes 7 and 8). Since the $\alpha$-CTD lacks the principal dimerization domain of $\alpha$, which is located in the $\alpha$-NTD (Blatter et al. 1994; Kimura et al. 1994), the complex obtained with NusA and the $\alpha$-CTD is likely to contain only one molecule each of the $\alpha$-CTD and NusA. In fact, we have reason to believe that the weak dimerization activity of the $\alpha$-CTD is abolished by the presence of NusA (see below). It is also possible,
A

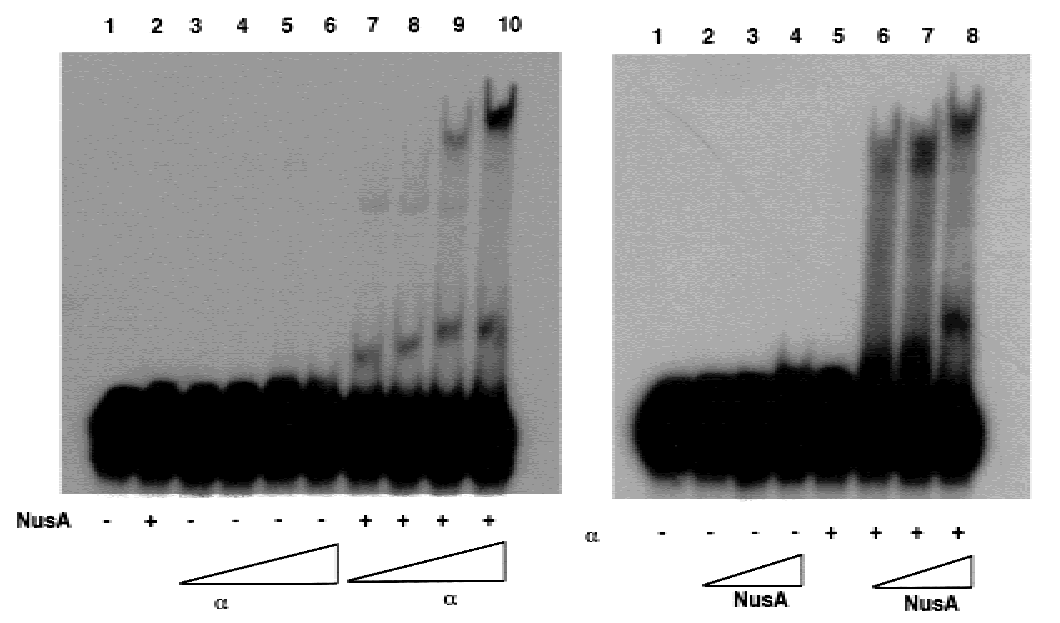

C

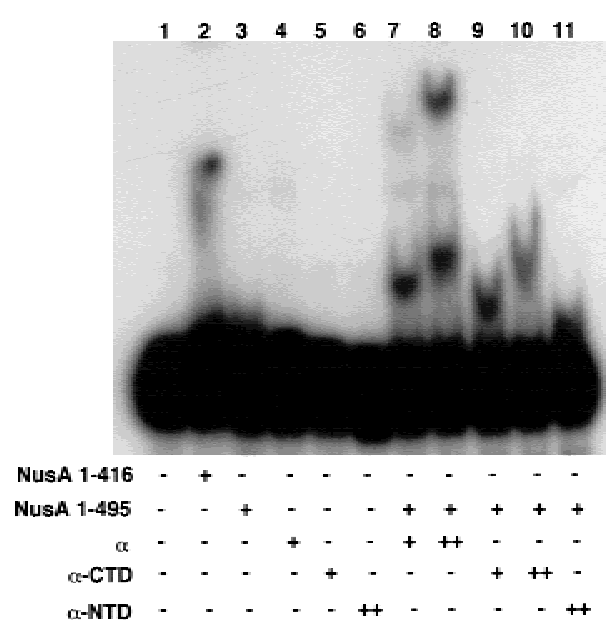

Figure 1. Binding of NusA to RNA in the presence of the RNA polymerase $\alpha$ subunit. $(A)$ Addition of increasing amounts of $\alpha$ to a constant amount of NusA results in an increase in complex formation. Reactions containing ${ }^{32} \mathrm{P}-\mathrm{labeled}$ nut-site RNA and various combinations of $14 \mu \mathrm{M}$ NusA and 1.25, 2.5, 5, or $10 \mu \mathrm{M} \alpha$ (as indicated) were electrophoresed on 7.5\% nondenaturing gels, dried, and exposed to film. $(B)$ Addition of increasing amounts of NusA to a constant amount of $\alpha$ results in increased complex formation. Reactions containing ${ }^{32} \mathrm{P}$-labeled nut-site RNA and various combinations of $9 \mu \mathrm{M} \alpha$ and 3.5, 7, or $14 \mu \mathrm{M}$ NusA (as indicated) were electrophoresed on $7.5 \%$ nondenaturing gels, dried, and exposed to film. $(C) \alpha$-CTD stimulates RNA binding by NusA. Reactions containing ${ }^{32} \mathrm{P}$-labeled nut-site RNA and various combinations of $13 \mu \mathrm{M}$ NusA or NusA (amino acids $1-416$ ), 4.5 or $9 \mu \mathrm{M} \alpha, 4.5$ or 9 $\mu \mathrm{M} \alpha$-CTD or $11 \mu \mathrm{M} \alpha$-NTD (as indicated) were electrophoresed on $7.5 \%$ nondenaturing gels, dried, and exposed to film. 
though unlikely, that NusA causes the $\alpha$-CTD to bind RNA, leading to the formation of a complex that contains the $\alpha$-CTD and RNA but no NusA. The additional lower-mobility complex in the reactions containing $\alpha$ and NusA (lanes 7 and 8) is likely to contain two molecules of, $\alpha$ and one or more molecules of NusA as a consequence of dimerization of the $\alpha$ subunits. In contrast, no distinct shift was obtained with NusA and the $\alpha$-NTD (lane 11). These results suggest that the CTD of the RNA-polymerase $\alpha$ subunit is capable of stimulating RNA binding by NusA.

\section{RNA binding by NusA in the presence of $\alpha$ is sequence-specific and sensitive to a mutation in the S1 homology region of NusA}

To evaluate potential RNA sequence or structure specificity in the RNA binding observed with NusA and $\alpha$, we compared the abilities of RNAs containing either a wildtype nut site or a nut site in which the sequence of the box $A$ element had been switched from $5^{\prime}-3^{\prime}$ to $3^{\prime}-5^{\prime}$ (box A reverse; Mogridge et al. 1995) to support formation of NusA- $\alpha$-nut-site complexes (Fig. 2A). Whereas $N$ only requires the $\operatorname{box} B$ RNA element for binding, NusA is unable to supershift an $\mathrm{N}$-nut-site complex when box $A$ is reversed (Mogridge et al. 1995). This suggests that there is a direct and specific interaction between box $A$ and an RNA-binding domain in NusA. As shown in Figure 2A, the low-mobility complexes formed with the wild-type probe, NusA, and $\alpha$ were not present in reactions when the reverse nut-site probe was used (cf. lane 4 with lane 8 ). Thus, the NusA binding promoted by $\alpha$ in these gel mobility shift experiments has structure- or sequence-specificity. Moreover, the importance of the boxA element for RNA binding provided additional evidence that the RNA binding observed in experiments containing NusA and $\alpha$ involves NusA.

The nusA R199A mutation causes a defect in antitermination by $\mathrm{N}$ in vivo, as well as a slight defect in the ability of NusA to supershift an N-nut-site complex, even though the NusA R199A mutant protein binds with normal affinity to N (T. Mah, Y. Zhou, N. Yu, J. Mogridge, E. Olsen, J. Greenblatt, and D. Friedman, unpubl.). Therefore, this mutation in the S1 homology region of NusA appears to cause a defect in the binding of NusA to nut-site RNA. As shown in Figure 2B, the nusA R199A mutation also prevented NusA from binding the nut-site RNA in the presence of $\alpha$ (cf. lanes 6 and 7). This result indicates that the $\mathrm{S} 1$ homology region of NusA is likely to participate in nut-site binding stimulated by $\alpha$ and provided further evidence that RNA binding observed in the presence of $\alpha$ and NusA reflects direct RNA binding by NusA.

\section{Interaction of $\alpha$ with the carboxy-terminal region} of NusA via modified helix-hairpin-helix motifs

Our observation that NusA could bind nut-site RNA in the presence of $\alpha$, but not in its absence, suggested that there may be a direct interaction between NusA and $\alpha$. To test for such a direct interaction between $\alpha$ and portions of NusA, a mixture of full-length NusA and three carboxy-terminally deleted mutant proteins (Fig. 3A, lane 2) was passed over columns containing various concentrations of covalently bound $\alpha$. Specific binding to $\alpha$, over and above the non-specific binding to the column matrix (lane 3), was observed only for the full-length NusA protein, whose binding increased in concert with the $\alpha$ concentration on the column (lanes 4-6). Since NusA (amino acids 1-416) did not bind to $\alpha$, the 79 carboxy-terminal amino acids of NusA are necessary for the binding of $\alpha$ to NusA. To further establish which regions of NusA are sufficient for interaction with $\alpha$, purified $\alpha$ was tested for binding to various covalently immobilized portions of NusA: an amino-terminal region, NusA (amino acids 1-137), that we have shown elsewhere to bind RNA polymerase (Mah et al. 1999); a carboxy-terminal fragment, NusA (amino acids 303-495); and the full-length protein (Fig. 3B). $\alpha$ did not bind to the aminoterminal fragment of NusA (lane 4), although binding to
A

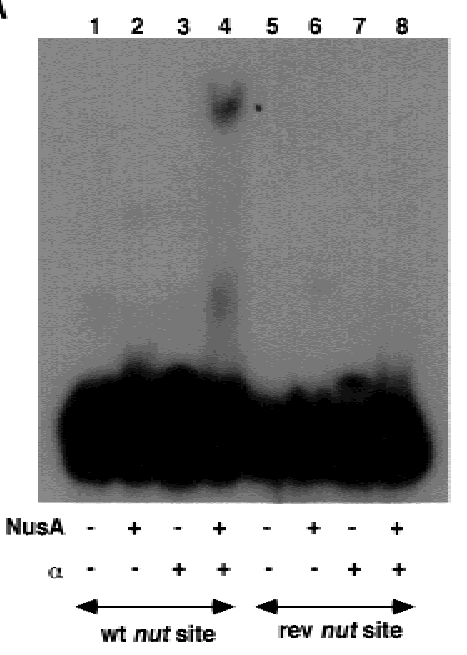

B

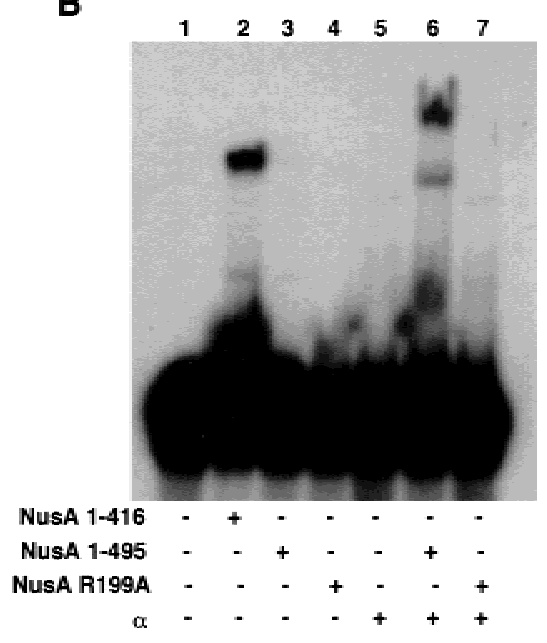

Figure 2. RNA binding by NusA in the presence of $\alpha$ is sequence-specific and sensitive to a mutation in the S1 domain of NusA. $(A)$ RNA binding by NusA in the presence of $\alpha$ is prevented by a mutation in the boxA portion of the nut site. Reactions containing wildtype or mutant ${ }^{32} \mathrm{P}$-labeled nut-site RNA (as indicated) and various combinations of $10 \mu \mathrm{M}$ $\alpha$ and $14 \mu \mathrm{M}$ NusA (as indicated) were electrophoresed on $7.5 \%$ nondenaturing gels, dried, and exposed to film. (B) RNA binding by NusA in the presence of $\alpha$ is prevented by a mutation in the S1 domain of NusA. Reactions containing ${ }^{32} \mathrm{P}$-labeled nut-site RNA and various combinations of $14 \mu \mathrm{M}$ NusA, 14 $\mu \mathrm{M}$ NusA (amino acids 1-416), or $12 \mu \mathrm{M}$ NusA R199A and $11 \mu \mathrm{M} \alpha$ (as indicated) were electrophoresed on $7.5 \%$ nondenaturing gels, dried, and exposed to film. 
Mah et al.

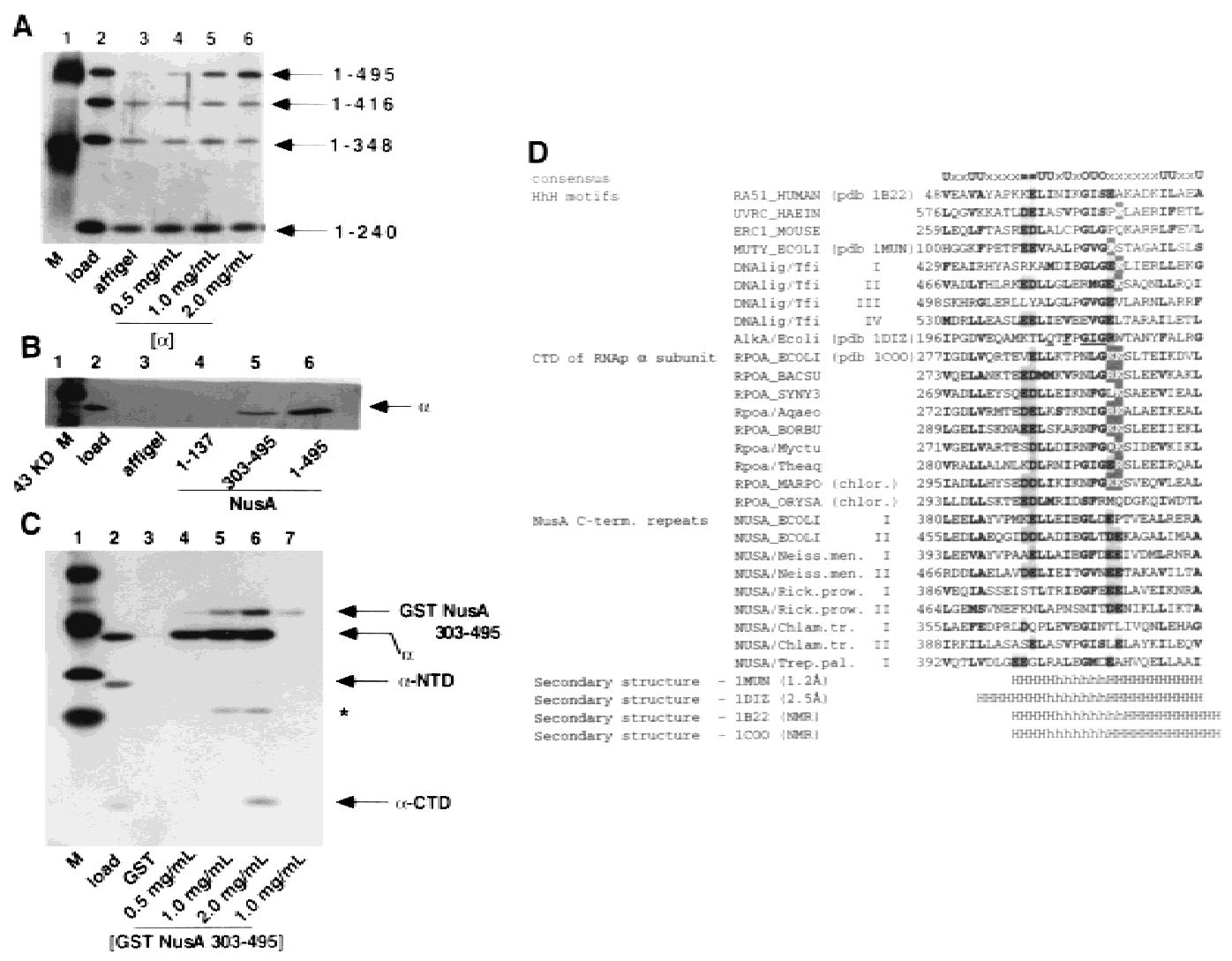

Figure 3. Interaction of $\alpha$ with the carboxy-terminal region of NusA. (A) Carboxy-terminal truncation of NusA prevents the $\alpha-N u s A$ interaction. A mixture of four His $_{6}$-tagged NusA proteins (lane 2) was passed over columns containing affigel (lane 3) or increasing amounts of affigel-coupled $\alpha$ (lanes 4-6). Bound proteins were eluted with buffer containing $1 \mathrm{M} \mathrm{NaCl,} \mathrm{subjected} \mathrm{to} \mathrm{SDS-PAGE,} \mathrm{and}$ stained with silver. $(B)$ The carboxy-terminal region of NusA interacts directly with $\alpha$. Buffer containing $\alpha$ and $0.2 \mathrm{mg} / \mathrm{ml}$ insulin (lane 2) was passed over columns containing affigel (lane 3) or affigel-coupled NusA (2 mg/ml) (lane 6) or affigel-coupled regions of NusA (lanes 4 and 5) (as indicated). The concentrations of amino- and carboxy-terminal regions of NusA on the columns were adjusted so that each had the same molar concentration as the full-length NusA. Bound protein was eluted with buffer containing $1 \mathrm{M} \mathrm{NaCl}$, subjected to SDS-PAGE, and stained with silver. $(C) \alpha$-CTD interacts with the 192 carboxy-terminal amino acids of NusA. A mixture of $\alpha, \alpha$-CTD, and $\alpha$-NTD (lane 2) was passed over columns containing GST (lane 3) or increasing amounts of GST-NusA (amino acids 303-495) (lanes 4-6). As a control, buffer alone was passed over a GST-NusA (amino acids 303-495) column (lane 7). Bound proteins were eluted with buffer containing $1 \mathrm{M} \mathrm{NaCl}$, subjected to SDS-PAGE, and stained with silver. * indicates a degradation product of $\alpha$, as identified by mass spectrometry. $(D)$ Helix-hairpin-helix motifs in the carboxy-terminal domains of bacterial RNA polymerase $\alpha$ subunits and NusA proteins. Identifiers in SWISSPROT and PDB databases are shown where available. Numbers indicate the distance, in amino acid residues, from the amino terminus of the protein. Roman numerals indicate the repeated motifs in the same protein. Residues conserved in many families of $\mathrm{HhH}$ proteins are indicated by bold type. Within the consensus line, certain categories are indicated: bulky hydrophobic residues (F, I, L, M, V, W, and Y; U in the consensus line), small side chains (A, G, and S; O in the consensus line), negatively charged residues ( $\mathrm{D}$ and $\mathrm{E}_{;}=$in the consensus line), and positively charged residues (K and $\mathrm{R}_{;}$outlined letters in the alignment). Residues that may participate in charge-charge interactions are boxed. Underlined letters in the E. coli AlkA mismatch repair glycosylase sequence indicate the amino acids whose side chains make contacts with the phosphate residues in the DNA backbone, either directly or by coordinating a metal ion. The known elements of secondary structure are indicated by $\mathrm{H}$ for helix and $\mathrm{h}$ for hairpin.

the carboxy-terminal fragment of NusA was observed (lane 5), and the binding of $\alpha$ was best with full-length NusA (lane 6). It appears, therefore, that $\alpha$ interacts primarily with the carboxy-terminal region of NusA.

Since the $\alpha$-CTD, but not the $\alpha$-NTD, allowed RNA binding by NusA (Fig. 1), we also tested which region of $\alpha$ was involved in the direct binding of $\alpha$ to NusA (Fig. 3C). Full-length $\alpha, \alpha-N T D$, and $\alpha$-CTD were mixed together (lane 2) and loaded onto columns containing GST (lane 3) or various concentrations of GST-NusA (amino acids 303-495) (lanes 4-6). The bound proteins were eluted with salt. None of the $\alpha$ fragments were retained on the control GST column. In contrast, as the concentration of immobilized GST-NusA (amino acids 303-495) on the columns was increased, increasing amounts of full-length $\alpha$ and $\alpha$-CTD were present in the salt eluates from this matrix. In contrast, the binding of $\alpha$-NTD to the immobilized GST-NusA (amino acids 303-495) was barely detectable (lanes 4-6). Therefore, the result of this direct protein-protein-binding study 
was consistent with the results of the gel mobility shift experiments, which indicated that only full-length $\alpha$ and the $\alpha$-CTD would interact with NusA. Because the $\alpha$-CTD bound less tightly to NusA than $\operatorname{did}$ intact $\alpha$, the weak binding of the $\alpha$-NTD to NusA may indicate that the $\alpha$-NTD makes a small contribution to the $\alpha-$ NusA interaction.

Sequence analysis of the regions of NusA located carboxy-terminal to the KH domains (Gibson et al. 1993a,b) revealed heterogeneity of this region among bacteria and archaea. Many bacteria and all archaea lack the carboxyterminal domain corresponding to the last 150 residues of $E$. coli NusA, including the 79-residue autoinhibitory sequence identified in this study. However, this segment is conserved in representatives of several divisions of Proteobacteria, such as $\alpha$-Proteobacteria (Rickettsia prowazekii), $\beta$-Proteobacteria (Neisseria meningitides), and $\gamma$-Proteobacteria (E. coli and others), as well as in two distant lineages of bacteria, namely, in Chlamydia and Treponema.

Using the PSI-BLAST program (Altschul et al. 1997), we detected sequence similarities among this carboxyterminal region of $E$. coli NusA, the amino-terminal domains of the eukaryotic/archaeal recombinases Rad51/ RadA, and the $\alpha$-CTD sequences from all completely sequenced bacteria. For example, when the carboxyterminal segment of NusA from Chlamydophila pneumoniae was used as a query, the first Rad51-like sequence was detected at the second iteration with the probability of a random match, $p=2 \times 10^{-3}$, and the first $\alpha$-CTD sequence was detected at the third iteration with $p=1 \times 10^{-4}$. When a homologous domain from E. coli was used to scan the database, it matched the Rad51 sequence with a $p$ value of $2 \times 10^{-4}$. If $\alpha$-CTD sequences were used as queries, the NusA regions were retrieved, typically interspersed with the Rad51 amino termini and the helix-hairpin-helix $(\mathrm{HhH})$ motifs from bacterial $\mathrm{NAD}^{+}$-dependent DNA ligases. Searches initiated with Rad51 protein sequences also retrieved ligases, NusA proteins, and the $\alpha$-CTDs, followed by other $\mathrm{HhH}$ proteins. Sequence similarities among NusA, the Rad51 amino-terminal domains, and the $\mathrm{HhH}$ motifs in DNA ligases have been mentioned recently (Aravind et al. 1999|, and matches to the $\alpha$-CTD of Thermus and Synechocystis have been automatically detected using the Hidden Markov Model of aligned HhH proteins (http:// smart.embl-heidelberg.de/; Schultz et al. 2000).

Multiple sequence alignment of the NusA proteins, the $\alpha$-CTDs, and $\mathrm{HhH}$ motifs (Fig. 3D) revealed two copies of an HhH-like motif in NusA proteins from the three above-mentioned divisions of Proteobacteria and in Chlamydia. Treponema appears to have lost one of the two copies owing to sequence drift, whereas in another spirochaete, Borrelia, both copies are disrupted (Fig. 3D; data not shown). Bacterial and chloroplast $\alpha$ subunits have one copy of the $\mathrm{HhH}$ motif, and its sequence is significantly deviated in most chloroplast proteins.

Superposition of the alignment and the known threedimensional structures of the various $\mathrm{HhH}$ proteins and the $\alpha$-CTD of E. coli indicates that the most conserved region corresponds to the two helices and the folded hairpin loop between them, with negatively charged residues frequently found in the first helix, small side-chain residues apparently required for folding of the hairpin, and a charged patch of varying polarity always found at the beginning of the second helix (Fig. 3D). The presence of the HhH motifs in DNA-binding and RNA-binding proteins has raised the suggestion that these motifs might mediate nucleic acid-protein interactions (Doherty et al. 1996), and direct involvement of the residues in the hairpin of the DNA glycosylase AlkA in hydrogen bonding with the phosphate backbone of DNA has been demonstrated (Hollis et al. 2000). Intriguingly, neither the $\alpha$-CTD nor NusA seems to utilize its $\mathrm{HhH}$ motif for nucleic acid binding; instead, the second $\mathrm{HhH}$ motif in NusA may prevent other parts of NusA from binding to RNA, and the HhH motif in the $\alpha$-CTD may facilitate $\alpha$-CTD- $\alpha$-CTD homodimer and $\alpha$-CTD-NusA heterodimer formation.

\section{A carboxy-terminally truncated Nus A also binds specifically to nut-site RNA}

Our observations that $\alpha$ could provoke RNA binding by NusA and interact with NusA (amino acids 1-495), but not with NusA (amino acids 1-416), was consistent with the possibility that the 79 carboxy-terminal amino acids of NusA might inhibit the RNA-binding activity of NusA. As shown in Figure 4A, NusA (amino acids 1-416), unlike full-length NusA, could bind RNA containing a wild-type nut site in a gel mobility shift experiment (lanes 2-7), but only weakly to RNA containing a nut site with a reversed boxA sequence (Fig. 4A, lanes 12-14). This indicates that the binding of NusA to nutsite RNA is indeed inhibited by the 79 carboxy-terminal amino acids of NusA and suggests that this inhibition could be relieved by an interaction of this portion of NusA with the CTD of the RNA polymerase $\alpha$ subunit.

In order to further characterize this $\alpha$-independent RNA binding by NusA (amino acids 1-416), other deletion mutants of NusA were tested for their ability to bind RNA containing a wild-type nut site in a gel mobility shift experiment (Fig. 4B). Carboxy-terminal truncation of NusA to amino acid 348 weakened RNA binding, even though NusA (amino acids 1-348) retains the $\mathrm{S} 1$ and $\mathrm{KH}$ homology regions (lane 4). The deletion of NusA's amino-terminal RNA-polymerase-binding region (Mah et al. 1999), as in NusA (amino acids 132-416), also prevented RNA binding by NusA (lane 2). Since two disruptions of NusA (amino acids 1-416) that do not delete its S1 and KH RNA-binding domains interfere with RNA binding, the use of these deletions alone did not allow us to assign any localized RNA-binding region. Because NusA (amino acids 132-416) and NusA (amino acids 1-348) appear to be folded proteins (Mah et al. 1999), perhaps the amino-terminal RNA-polymerasebinding region in amino acids 1-137 of NusA, as well as amino acids $348-415$ of NusA, may be required to stabilize the RNA-binding ability of NusA (amino acids $1-416)$. 
Mah et al.

A

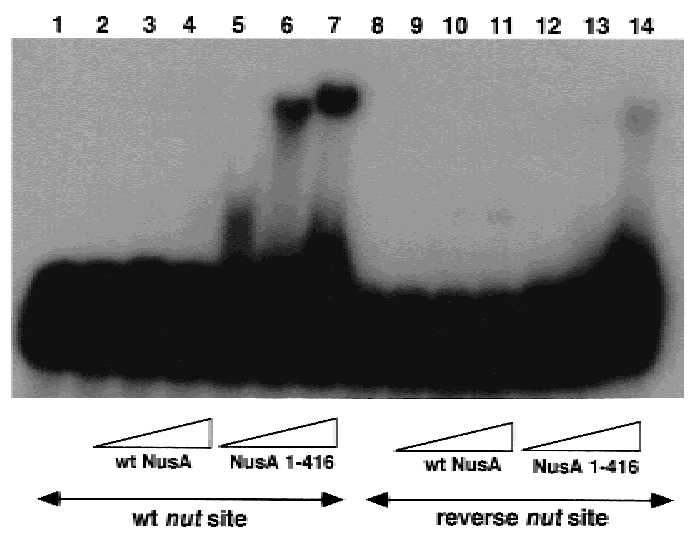

B

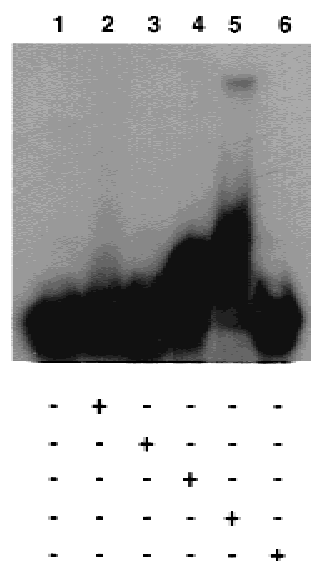

Figure 4. A carboxy-terminally truncated NusA binds specifically to nut-site RNA. (A) RNA binding by NusA (amino acids 1-416) is prevented by a mutation in the boxA portion of the nut site. Reactions containing wild-type or mutant ${ }^{32} \mathrm{P}$-labeled nut-site RNA (as indicated) and 3.5, 7, or $14 \mu \mathrm{M}$ NusA or NusA (amino acids 1-416) (as indicated) were electrophoresed on 7.5\% nondenaturing gels, dried, and exposed to film. (B) RNA binding by NusA (amino acids 1-416) is stabilized by amino acids 1-137 and 348-415 of NusA. Reactions containing ${ }^{32}$ P-labeled nut-site RNA and $10 \mu \mathrm{M}$ NusA (amino acids 132-416), NusA (amino acids 132-495), NusA (amino acids 1-348), NusA (amino acids 1-416) or NusA (as indicated) were electrophoresed on 7.5\% nondenaturing gels, dried, and exposed to film.

\section{The $\lambda N$ protein binds the carboxy-terminal region} of NusA

The $\mathrm{N}$ protein of the bacteriophage $\lambda$ also binds NusA (Greenblatt and Li 1981b), and we have shown that this binding requires carboxy-terminal amino acids of NusA (Mah et al. 1999). In view of the possibility that $\alpha$ and $N$ might act in similar ways to provoke RNA binding by NusA, we tested various fragments of NusA for binding to N. Full-length NusA, a carboxy-terminally truncated NusA, NusA (amino acids 1-399), and a carboxy-terminal fragment of NusA, NusA (amino acids 303-495), were mixed with E. coli extracts and passed over GST and GST-N affinity columns (Fig. 5). None of the major E. coli proteins present in the extracts applied to the columns bound to the GST or GST-N columns (lanes 2, $3,5,6,8$, and 9). Both NusA and NusA (303-495) bound selectively to GST-N and therefore were present in the high salt eluates from the GST-N columns, but not the GST control columns (lanes 2, 3, 8, and 9). NusA (1-399) was absent from the high salt eluates of both columns (lanes 5 and 6). Thus, $\mathrm{N}$ binds directly to the carboxyterminal region of NusA. This result suggested that $\mathrm{N}$ might activate the RNA-binding ability of NusA by binding to the same region of NusA that we have shown binds $\alpha$.

The interaction between NusA and $\alpha$ is not necessary for NusA to stimulate termination if NusA lacks its carboxy-terminal autoinhibitory domain

The interaction between NusA and $\alpha$ may be important for NusA function in termination (Liu et al. 1996) because it allows NusA to interact with RNA. We have previously shown that a NusA fragment lacking the car- boxy-terminal inhibitory domain retains wild-type function in termination and antitermination assays in vitro (Mah et al. 1999). A similarly truncated form of NusA supports the growth of E. coli and transcriptional antitermination by $\mathrm{N}$ in vivo (Tsugawa et al. 1988). If the interaction between NusA and $\alpha$ is necessary for fulllength NusA to interact with RNA and stimulate termination, then a carboxy-terminally truncated NusA protein would still be functional in transcription termination assays performed with a mutant RNA polymerase lacking the $\alpha$-CTD, even though full-length NusA would

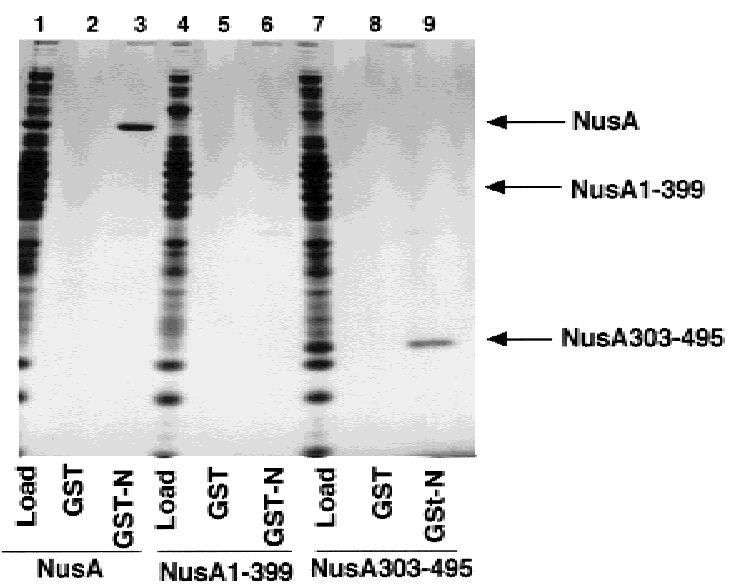

Figure 5. The $\lambda \mathrm{N}$ protein binds directly to the 192 carboxyterminal amino acids of NusA. E. coli extract containing additional NusA (lane 1), NusA (amino acids 1-399) (lane 4), or NusA (amino acids 303-495) (lane 7) was passed over columns containing $2 \mathrm{mg} / \mathrm{ml} \mathrm{GST}$ (lanes 2, 5, and 8) or $0.5 \mathrm{mg} / \mathrm{ml} \mathrm{GST-N}$ (lanes 3, 6, and 9). Bound proteins were eluted with buffer containing $1 \mathrm{M} \mathrm{NaCl}$, subjected to SDS-PAGE, and stained with silver. 
not be functional in these conditions. To test this idea, in vitro transcription assays were performed on a template containing the T7 A1 promoter and the $\lambda$ tR 2 terminator (Fig. 6). In reactions with wild-type RNA polymerase, both the wild-type NusA (1-495) and the carboxy-terminally truncated NusA (1-348) decreased the terminator read-through of the tR2 terminator from $39 \%$ to $11 \%$ and $15 \%$, respectively (lanes $5-7$ ). In contrast, whereas reactions with RNA polymerase lacking the $\alpha$-CTD yielded a lower level of terminator read-through (29\%) compared to the level that was obtained with wild-type RNA polymerase (39\%), only NusA (1-348) but not wild-type NusA decreased the amount of terminator read-through in this case (lanes 2-4). These results are consistent with the idea that the interaction of the $\alpha$-CTD with NusA is necessary for full-length NusA to stimulate termination because the interaction allows full-length NusA to bind the nascent RNA.

\section{Discussion}

An autoinhibition domain may inhibit RNA binding by NusA

Whereas full-length NusA does not bind RNA, we have shown here that a carboxy-terminal deletion mutant,
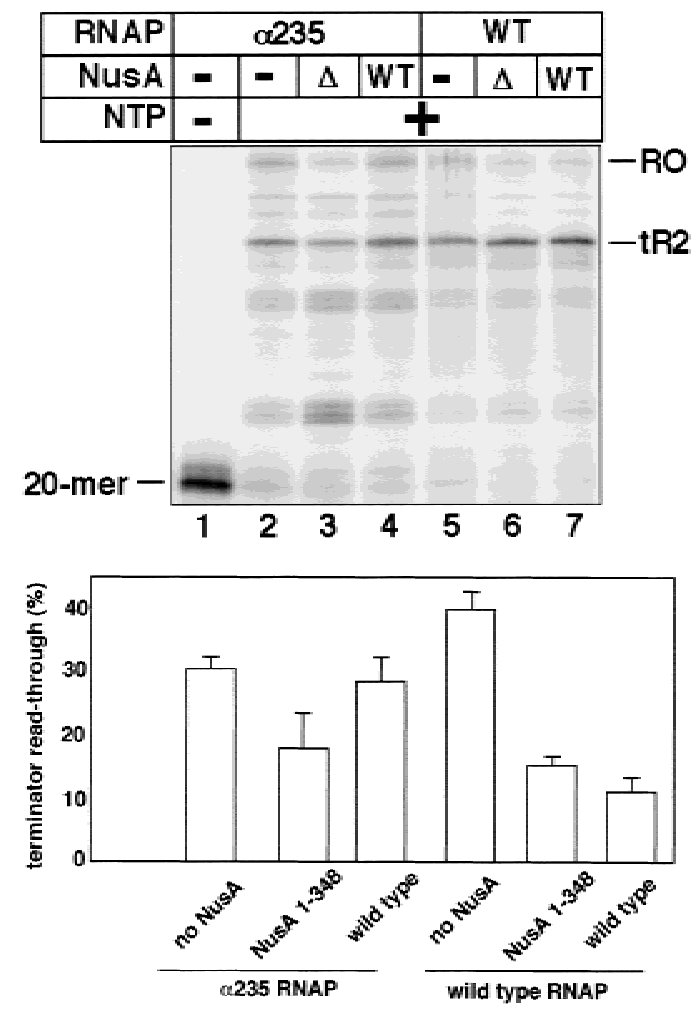

Figure 6. The carboxy-terminal region of NusA is not necessary for enhancement of termination by NusA if a mutant RNA polymerase lacking the $\alpha$-CTD is used. In vitro transcription reactions with wild-type RNA polymerase or a mutant RNA polymerase lacking the carboxy-terminal domain of the $\alpha$ subunit were incubated with either no NusA, NusA 1-348 $(\Delta)$, or NusA 1-495 (WT). The bar graph is based on the average values from 4 different experiments, only one of which is shown here.
A
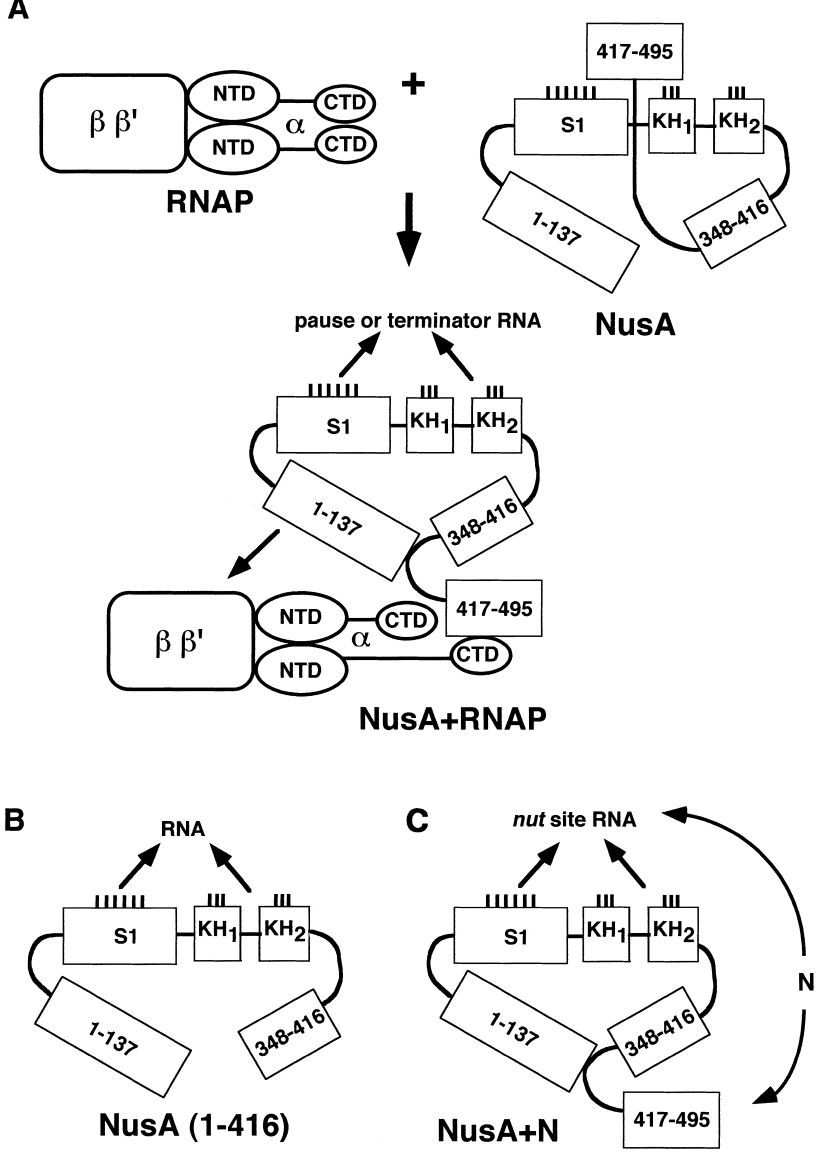

Figure 7. Model for NusA function in elongation, termination, and antitermination. See text for details.

NusA (1-416), which retains the S1 and KH homology regions of NusA but only one of its two $\mathrm{HhH}$ motifs, can bind RNA in the absence of $\alpha$ or $\mathrm{N}$. This suggests that one or more of the RNA-binding domains of NusA may be occluded by the second $\mathrm{HhH}$ motif or other determinants within the 79 carboxy-terminal amino acids of NusA, as diagramed in the model shown in Figure 7A. Since neither NusA (1-348) nor NusA (132-416) binds RNA as strongly as NusA (1-416), amino acids 1-131 and 349-416 must also alter the folding, alignment, or accessibility of the RNA-binding domains (Fig. 7A), and it is possible that the first $\mathrm{HhH}$ motif in amino acids $381-410$ of NusA contributes to RNA binding. Interaction of carboxy-terminally truncated NusA (1-416) with RNA is sensitive to alteration of the boxA portion of the nut site (Fig. 4A), as is also the case when full-length NusA binds the nut-site RNA in the presence of $\mathrm{N}$ (Mogridge et al. 1995) or $\alpha$ (Fig. 2A). RNA binding by NusA (1-416) is also inhibited when alterations in the loop of box $B$ prevent box $B$ from forming a GNRA tetralooplike structure (Legault et al. 1998; T. Mah, and J. Greenblatt, unpubl.). The inability of full-length NusA to bind RNA resembles the inability of the intact initiation subunit $\sigma^{70}$ of RNA polymerase to bind DNA unless it is part of the RNA polymerase holoenzyme (Dombroski et al. 1992, 
1993). Just as deletion of the carboxy-terminal HhH motif of NusA enables NusA to bind RNA in the absence of RNA polymerase, deletion of the 130 amino-terminal amino acids of $\sigma^{70}$ enables $\sigma^{70}$ to interact specifically and nonspecifically with DNA in the absence of the other RNA polymerase subunits (Dombroski et al. 1992). It is postulated that this autoinhibition of DNA binding by $\sigma^{70}$ is relieved when $\sigma^{70}$ interacts with the core polymerase subunits and undergoes a conformational change that uncovers or reorients its DNA-binding domains (Dombroski et al. 1992, 1993; Malhotra et al. 1996). It is intriguing that two prokaryotic proteins that compete for binding to the RNA polymerase core enzyme (Greenblatt and Li 1981a) may use similar mechanisms to control their nucleic acid-binding ability.

\section{Interaction of Nus $A$ with $\alpha$ : relationship to RNA binding and transcription termination}

Our observation that the $\alpha$ subunit of RNA polymerase stimulates RNA binding by NusA is consistent with previous studies showing that NusA can be cross-linked to the nascent transcript in transcription complexes (Liu and Hanna 1995). We propose that this effect of $\alpha$ on RNA binding by NusA is the consequence of a direct interaction between the two proteins, as documented in our affinity chromatography experiments and illustrated in Figure 7A. The binding of NusA to $\alpha$ and stimulation of RNA binding by $\alpha$ appear to be mediated mainly by the carboxy-terminal domain of $\alpha$ (Figs. 1 and 3C). The $\alpha$-CTD was implicated previously in the ability of NusA to stimulate pausing and termination by RNA polymerase (Liu et al. 1996). The interaction between NusA and $\alpha$ is probably mediated by a region of homology between these two proteins, consisting of one or two copies of the helix-hairpin-helix motif per protein. This region is most likely also involved in $\alpha$-CTD dimer formation, and we propose that the homologous region in NusA interacts with one of the $\alpha$ monomers to disrupt $\alpha$-dimer formation (Fig. 7A). In the $\mathrm{NAD}^{+}$-dependent DNA ligase from Thermus filiformis, four copies of the $\mathrm{HhH}$ motif form a compact cluster with all hairpins pointing in one direction; this cluster is apparently stabilized through the interactions between side chains from different helices (Lee et al. 2000). Given that the interaction between NusA and the $\alpha$-CTD is likely to involve their HhH-like motifs, one can speculate that similar helix bundling may occur when these motifs are found on separate molecules. A preponderance of positively charged residues at the amino termini of the longer helices in the $\alpha$-CTD and frequent occurrence of negative charges in the equivalent positions of the NusA $\mathrm{HhH}$ motifs provoke the speculation that these amino acids might be required for the interaction between NusA and the $\alpha$-CTD.

RNA binding either by truncated NusA or by fulllength NusA in the presence of $\alpha$ is weak. Nevertheless, the dependence of RNA binding by truncated or fulllength NusA in the presence of $\alpha$ on the boxA sequence in the nut site is similar to the effect of boxA on RNA binding by NusA in the presence of $\mathrm{N}$ (Mogridge et al.
1995). Our ability to abrogate RNA binding by deleting the $\alpha$-CTD or portions of NusA also suggests that RNA binding genuinely involves both $\alpha$ and NusA.

From the data presented here, we hypothesize that full-length NusA is prevented from interacting with RNA by an autoinhibition mediated by its 79 carboxyterminal amino acids (cf. Fig. 7A with Fig. 7B). We suggest that during elongation, NusA uses its RNA-polymerase-binding region in amino acids $1-137$ (Mah et al. 1999 ) to interact with RNA polymerase subunits $\beta$ and $\beta^{\prime}$, and its carboxy-terminal region to interact with $\alpha$ (Fig. 7A). The interaction with $\alpha$ may then cause a conformational change in NusA such that its RNA-binding domains either fold or become exposed and competent to bind the nascent RNA. Thus, as part of the transcription complex, NusA would be in a position to bind and stabilize pause and termination motifs in the nascent RNA, leading to enhancement of pausing and termination at certain sites. We suggest that the interaction of the $\alpha$-CTD with NusA is essential for NusA to stimulate termination only if the inhibitory carboxy-terminal region of NusA is present and not if it is deleted. In other experiments we have shown that NusA (1-416) is able to stimulate termination (Mah et al. 1999). This fragment of NusA cannot interact with $\alpha$, but it lacks the inhibitory region and can bind RNA on its own. In many bacteria (e.g., the Gram-positive, blue-green, and $\varepsilon$-Proteobacteria), the NusA proteins lack the carboxy-terminal $\mathrm{HhH}$ region. In these organisms, NusA may be able to bind RNA and stimulate pausing and termination in the absence of any direct interaction with $\alpha$. E. coli strains that lack the carboxy-terminal domains of NusA are temperature sensitive (Tsugawa et al. 1988).

The interaction between the amino-terminal RNA polymerase-binding region of NusA (amino acids 1-137) and RNA polymerase is essential for function because the loss of the amino-terminal RNA polymerase-binding region results in the inability of NusA to participate in termination and antitermination (Mah et al. 1999). Since we have shown that $\alpha$ alone does not bind the aminoterminal region of NusA, and since there is cross-linking data (J. Li and J. Greenblatt, unpubl.) and other evidence (Liu et al. 1996) to suggest that $\beta$ and $\beta^{\prime}$ interact directly with NusA, it is likely that one or both of the two large RNA polymerase subunits contact the amino-terminal RNA-polymerase-binding region of NusA (Fig. 7A). Nevertheless, a weak but important interaction between $\alpha$ and this region of NusA cannot be ruled out.

\section{Transcriptional antitermination by $N$}

We also showed that $\mathrm{N}$ interacts with this same carboxyterminal autoinhibitory region of NusA. Therefore, we propose that $\mathrm{N}$ activates the RNA-binding activity of NusA in a manner similar to that of $\alpha$, as modeled in Figure $7 \mathrm{C}$. In this scheme, the close proximity of NusA to both the nut site and $\mathrm{N}$ could result in exclusive binding of NusA to the nut-site RNA. Such an interaction might then serve two purposes: first, the interaction of NusA with nut-site RNA would prevent pause and ter- 
mination sequences in the nascent RNA from binding to NusA, and this would prevent NusA from enhancing pausing and termination; second, the NusA-nut-site interaction, together with interactions involving other Nus factors, N, RNA polymerase, and the nut-site RNA, would increase the overall stability of the antitermination complex containing $\mathrm{N}$.

Ordinary elongation complexes assembled in vitro contain one molecule of NusA, whereas there is evidence that elongation complexes containing the $\lambda \mathrm{N}$ protein contain two molecules of NusA (Horwitz et al. 1987). Therefore N-modified elongation complexes may have one molecule of NusA interacting with $\mathrm{N}$ and the other with $\alpha$, or, alternatively, each of the two NusA molecules may interact with one of the two $\alpha$ molecules in RNA polymerase.

Friedman and colleagues have shown that a point mutation in the $\alpha$-CTD, as well as deletion of the entire $\alpha$-CTD, enhances antitermination by $\mathrm{N}$ in vivo (Schauer et al. 1996). Furthermore, even though loss of the $\alpha$-CTD prevents NusA from stimulating termination in vitro, it has no effect on the ability of NusA to stimulate antitermination mediated by the $\mathrm{N}$ protein in vitro (Liu et al. 1996). These data suggest that there may be a competition between $\alpha$ and $\mathrm{N}$ for binding to the carboxy-terminal region of NusA. Interaction of $\alpha$ with NusA may direct NusA to the nascent transcript near its $3^{\prime}$ end and facilitate pausing and termination, whereas interaction of $\mathrm{N}$ with NusA would block the interaction between NusA and $\alpha$, direct NusA to the nut-site RNA, and prevent NusA from stimulating pausing and termination. If this model is correct, it would resolve the long-standing paradox that the same molecule, NusA, can participate in both termination (Greenblatt et al. 1981; Grayhack and Roberts 1982; Schmidt and Chamberlin 1987; Whalen et al. 1988) and antitermination (Friedman 1971; Das and Wolska 1984; Horwitz et al. 1987) of transcription.

\section{Materials and methods}

\section{Plasmids, strains, and reagents}

RNA polymerase, NusA, GST-NusA proteins, GST-N, His $_{6}-$ tagged NusA proteins, $\alpha$, and $\alpha_{235}$ were purified as previously described (Burgess and Jendrisak 1975; Greenblatt and Li 1981b; Mogridge et al. 1998; Mah et al. 1999). Purified $\alpha$-CTD was provided by G. Zhang and S. Darst. NusA R199A was provided by Ying Zhou and David Friedman. Purification for this protein is described elsewhere (T. Mah, Y. Zhou, N. Yu, J. Mogridge, E. Olsen, J. Greenblatt, and D. Friedman, unpubl.).

The oligonucleotides used for cloning were purchased from ACGT Corp. (Toronto). RNAguard was bought from Pharmacia Biotech. Restriction enzymes and DNA ligase were purchased from New England Biolabs. T7 RNA polymerase was obtained from Life Technologies.

\section{Construction of GST-NusA proteins}

PCR primers were designed to amplify fragments of NusA from the plasmid J1150. Forward and reverse primers contained
BamHI and EcoRI restriction sites, respectively, for subsequent cloning into the vector pGEX-2T (Pharmacia).

\section{Purification of GST-NusA proteins}

The E. coli strain $\mathrm{DH} 5 \alpha$ (Life Technologies) containing the GST-NusA fusion plasmid was grown in 1 liter of LB medium to an $\mathrm{A}_{600}$ of 0.5 and induced for $3 \mathrm{~h}$ with $0.5 \mathrm{mM}$ isopropyl-1thio- $\beta$-D-galactopyranoside. Cells were harvested by centrifugation, resuspended, and sonicated in $10 \mathrm{ml}$ of $1 \mathrm{M} \mathrm{NaCl}$ Buffer A (20 mM Tris-HCl, pH 7.8, 0.2 mM EDTA, 1 mM dithiothreitol, $1 \mathrm{mM}$ phenylmethylsulfonyl fluoride) and then centrifuged for $20 \mathrm{~min}$ at $12,000 \mathrm{rpm}$ in a Sorval SS34 rotor. Glutathione-sepharose $4 \mathrm{~B}$ beads ( $1 \mathrm{ml}$; Pharmacia) were added to the supernatant, and this slurry was rotated for $1 \mathrm{~h}$ at $4^{\circ} \mathrm{C}$. The beads were washed and resuspended in $500 \mu \mathrm{l}$ thrombin cleavage buffer $(50$ $\mathrm{mM}$ Tris- $\mathrm{HCl} \mathrm{pH}$ 7.5, $150 \mathrm{mM} \mathrm{NaCl}, 2.5 \mathrm{mM} \mathrm{CaCl}_{2}$ ). Thrombin was added to the slurry and incubated at room temperature for $1 \mathrm{~h}$. After centrifugation at $3000 \mathrm{rpm}$ in a tabletop Eppendorf microfuge, the supernatant was collected and dialyzed into 0.1 $\mathrm{M} \mathrm{NaCl}$ ACB (10 mM HEPES pH 7.0, 10\% glycerol, $0.1 \mathrm{mM}$ EDTA, $1 \mathrm{mM}$ DTT).

\section{Affinity chromatography}

Experiments with GST, GST-N, and GST-NusA (amino acids 303-495) were performed as previously described (Mah et al. 1999), except that the GST and GST-N columns were loaded with E. coli extract containing either NusA or NusA fragments cleaved from GST with thrombin, and the GST and GST-NusA (amino acids 303-495) columns were loaded with a mixture of $\alpha$, $\alpha-\mathrm{NTD}$, and $\alpha$-CTD, buffer, and $0.2 \mathrm{mg} / \mathrm{ml}$ insulin.

Experiments with the $\alpha$ subunit of RNA polymerase were done in two ways. In the first case, $\alpha$ was coupled to affigel 10 matrix (BioRad) at three different concentrations. Twenty microliters of beads were added to 200 - $\mu$ l pipette tips that contained $10 \mu \mathrm{l}$ of 212-300-micron glass beads (Sigma). The column bed was washed with 10 column volumes of $1 \mathrm{M} \mathrm{NaCl} \mathrm{ACB} \mathrm{(10}$ $\mathrm{mM}$ HEPES at $\mathrm{pH} 7.0,10 \%$ glycerol, $0.1 \mathrm{mM}$ EDTA, $1 \mathrm{mM}$ DTT) and then washed with 10 column volumes of $100 \mathrm{mM}$ $\mathrm{NaCl} \mathrm{ACB}$. Columns were loaded with a mixture of his-tagged NusA deletion proteins as well as full-length his-tagged NusA, buffer, and $0.2 \mathrm{mg} / \mathrm{ml}$ insulin. In the second case, his-tagged NusA (amino acids 1-495), GST-NusA (amino acids 1-137), and GST-NusA (amino acids 303-495) were coupled to affigel 10 at equimolar concentrations. Twenty microliters of beads were added to $200-\mu l$ pipette tips. The columns were treated as described above except that these columns were loaded with buffer containing $\alpha$ and $0.2 \mathrm{mg} / \mathrm{ml}$ insulin.

\section{Gel mobility shift experiments}

Gel mobility shift assays were performed as previously described (Mogridge et al. 1995) except that the proteins were added together and incubated on ice for $20 \mathrm{~min}$. Radiolabeled probe $(20-50 \mathrm{pM})$ was then added, and incubation on ice continued for an additional $10 \mathrm{~min}$. Concentrations of proteins are indicated in the figure legends.

\section{Sequence analysis}

The PSI-BLAST program (Altschul et al. 1997) was used for the iterative searches of sequence databases. In the first-pass search, sequences with a probability of random matching of 0.001 or lower were included in the profile, whereas at the further iterations the cutoff was set at 0.01 . Multiple sequence alignments 
were constructed using the combination of segment pair overlap and Gibbs sampling options of the MACAW program (Schuler et al. 1991).

\section{In vitro transcription}

RNA polymerases containing histidine-tagged mutant or wildtype $\alpha$ were prepared by our standard in vitro reconstitution procedure (Tang et al. 1995). About $0.5 \mu \mathrm{g}$ of RNA polymerase was used to prepare elongation complexes stalled at position 20 on a T7 A1 promoter-containing fragment fused to the tR2 terminator (template 1 from Nudler et al. 1995). Stalled, immobilized transcription complexes were washed, NusA was added to the final concentration of $100 \mathrm{nM}$, and elongation was resumed by the addition of nucleoside triphosphates to the final concentration of $100 \mu \mathrm{M}$. The reaction was allowed to proceed at $37^{\circ} \mathrm{C}$ for $5 \mathrm{~min}$ and terminated by the addition of urea-containing loading buffer. Reaction products were resolved by $6 \%$ denaturing PAGE, visualized by autoradiography and quantified by phosphoimagery.

\section{Acknowledgments}

The authors thank Joyce Li for constructing the strains of histagged deletion mutants of NusA. This work was supported by the Medical Research Council of Canada (MRC). J.G. is an International Research Scholar of the Howard Hughes Medical Institute and an MRC Distinguished Scientist. A.M. is supported in part by NIH grant GM58331. K.S. is supported in part by NIH RO1 grant GM59295.

The publication costs of this article were defrayed in part by payment of page charges. This article must therefore be hereby marked "advertisement" in accordance with 18 USC section 1734 solely to indicate this fact.

\section{References}

Altschul, S.F., Madden, T.L., Schaffer, A.A., Zhang, J., Zhang, Z., Miller, W., and Lipman, D.J. 1997. Gapped BLAST and PSI-BLAST: A new generation of protein database search programs. Nucleic Acids Res. 25: 3389-3402.

Aravind, L., Walker, D.R., and Koonin, E.V. 1999. Conserved domains in DNA repair proteins and evolution of repair systems. Nucleic Acid Res. 27: 1223-1242.

Artsimovich, I. and Landick, R. 1998. Interaction of a nascent RNA structure with RNA polymerase is required for hairpindependent transcriptional pausing but not for transcript release. Genes \& Dev. 12: 3110-3122.

Blatter, E.E., Ross, W., Tang, H., Gourse, R.L., and Ebright, R.H. 1994. Domain organization of RNA polymerase $\alpha$ subunit: C-terminal 85 amino acids constitute a domain capable of dimerization and DNA binding. Cell 78: 889-896.

Burgess, R.R. and Jendrisak, J.J. 1975. A procedure for the rapid, large-scale purification of Escherichia coli DNA-dependent RNA polymerase involving Polymin $\mathrm{P}$ precipitation and DNA-cellulose chromatography. Biochemistry 14: 4634-4638.

Bycroft, M., Hubbard, T.J., Proctor, M., Freund, S.M., and Murzin, A.G. 1997. The solution structure of the S1 RNA binding domain: A member of an ancient nucleic acid-binding fold. Cell 88: 235-242.

Das, A. and Wolska, K. 1984. Transcription antitermination in vitro by $\lambda N$ gene product: Requirement for a phage nut site and the products of host nusA, nusB, and nusE genes. Cell 38: $165-173$.

de Crombrugge, B., Mudryj, M., DiLauro, R., and Gottesman, M.
1979. Specificity of the bacteriophage $\lambda N$ gene product $(\mathrm{pN})$ : nut sequences are necessary and sufficient for antitermination by pN. Cell 18: 1145-1151.

Dejgaard, K. and Leffers, H. 1996. Characterisation of the nucleic-acid-binding activity of $\mathrm{KH}$ domains. Different properties of different domains. Eur. J. Biochem. 241: 425-431.

Dodson, R.E. and Shapiro, D.J. 1997. Vigilin, a ubiquitous protein with $14 \mathrm{~K}$ homology domains, is the estrogen-inducible vitellogenin mRNA 3 '-untranslated region-binding protein. J. Biol. Chem. 272: 12249-12252.

Doherty, A.J., Serpell, L.C., and Ponting, C.P. 1996. The helixhairpin-helix DNA-binding motif: A structural basis for non-sequence-specific recognition of DNA. Nucleic Acids Res. 24: 2488-2497.

Dombroski, A.J., Walter, W.A., Record, M.T., Jr., Siegele, D.A., and Gross, C.A. 1992. Polypeptides containing highly conserved regions of transcription initiation factor $\sigma^{70}$ exhibit specificity of binding to promoter DNA. Cell 70: 501-512.

Dombroski, A.J., Walter, W.A., and Gross, C.A. 1993. Aminoterminal amino acids modulate $\sigma$-factor DNA-binding activity. Genes \& Dev. 7: 2446-2455.

Ebright, R.H. and Busby, S. 1995. The Escherichia coli RNA polymerase $\alpha$ subunit: Structure and function. Curr. Opin. Genet. Dev. 5: 197-203.

Friedman, D.I. 1971. A bacterial mutant affecting $\lambda$ development. In The bacteriophage lambda (ed. A.D. Hershey), pp. 733-738. Cold Spring Harbor Laboratory Press, Cold Spring Harbor, New York.

Friedman, D.I. 1988. Regulation of phage gene expression by termination and antitermination of transcription. In The bacteriophages, Vol. 2 (ed. R. Calendar), pp. 263-319. Plenum, New York

Friedman, D.I. and Baron, L.S. 1974. Genetic characterization of a bacterial locus involved in the activity of the $N$ function of phage $\lambda$. Virology 58: 141-148.

Friedman, D.I. and Olson, E.R. 1983. Evidence that a nucleotide sequence, "box $A$," is involved in the action of the NusA protein. Cell 34: 143-149.

Gibson, T.J., Rice, P.M., Thompson, J.D., and Heringa, J. 1993a. $\mathrm{KH}$ domains within the FMR1 sequence suggest that fragile $\mathrm{X}$ syndrome stems from a defect in RNA metabolism. Trends Biochem. Sci. 18: 331-333.

Gibson, T.J., Thompson, J.D., and Heringa, J. 1993b. The KH domain occurs in a diverse set of RNA-binding proteins that include the antiterminator NusA and is probably involved in binding to nucleic acid. FEBS Lett. 324: 361-366.

Grayhack, E.J. and Roberts, J.W. 1982. The phage $\lambda$ Q gene product: Activity of a transcription antiterminator in vitro. Cell 30: $637-648$

Greenblatt, J. and Li, J. 1981a. The nusA gene protein of Escherichia coli. Its identification and a demonstration that it interacts with the gene $N$ transcription anti-termination protein of bacteriophage $\lambda$. J. Mol. Biol. 147: 11-23.

Greenblatt, J. and Li, J. 1981b. Interaction of the $\sigma$ factor and the nusA gene protein of $E$. coli with RNA polymerase in the initiation-termination cycle of transcription. Cell 24: 421428.

Greenblatt, J., McLimont, M., and Hanly, S. 1981. Termination of transcription by nusA gene protein of Escherichia coli. Nature 292: 215-220.

Greenblatt, J., Nodwell, J.R., and Mason, S.W. 1993. Transcriptional antitermination. Nature 364: 401-406.

Hollis, T., Ichikawa, Y., and Ellenberger, T. 2000. DNA bending and a flip-out mechanism for base excision by the helixhairpin-helix DNA glycosylase, Escherichia coli AlkA. EMBO J. 19: 758-766. 
Horwitz, R.J., Li, J., and Greenblatt, J. 1987. An elongation control particle containing the $N$ gene transcriptional antitermination protein of bacteriophage $\lambda$. Cell 51: 631-641.

Kimura, M., Fujita, N., and Ishihama, A. 1994. Functional map of the $\alpha$ subunit of Escherichia coli RNA polymerase. Deletion analysis of the amino-terminal assembly domain. $J$. Mol. Biol. 242: 107-115.

Landick, R. and Yanofsky, C. 1987. Isolation and structural analysis of the Escherichia coli trp leader paused transcription complex. J. Mol. Biol. 196: 363-377.

Lee, J.Y., Chang, C., Song, H.K., Moon, J., Yang, J.K., Kim, H.K., Kwon, S.T., and Suh, S.W. 2000. Crystal structure of $\mathrm{NAD}(+)$-dependent DNA ligase: Modular architecture and functional implications. EMBO J. 19: 1119-1129.

Legault, P., Li, J., Mogridge, J., Kay, L.E., and Greenblatt, J. 1998. NMR structure of the bacteriophage $\lambda \mathrm{N}$ peptide/boxB RNA complex: Recognition of a GNRA fold by an arginine-rich motif. Cell 93: 289-299.

Liu, K. and Hanna, M.M. 1995. NusA contacts nascent RNA in Escherichia coli transcription complexes. I. Mol. Biol. 247: 547-558.

Liu, K., Zhang, Y., Severinov, K., Das, A., and Hanna, M.M. 1996. Role of Escherichia coli RNA polymerase $\alpha$ subunit in modulation of pausing, termination and anti-termination by the transcription elongation factor NusA. EMBO J. 15: 150161.

Mah, T.F., Li, J., Davidson, A.R., and Greenblatt, J. 1999. Functional importance of regions of Escherichia coli elongation factor NusA that interact with RNA polymerase, the bacteriophage $\lambda$ N protein and RNA. Mol. Micro. 34: 523-537.

Malhotra, A., Severinova, E., and Darst, S.A. 1996. Crystal structure of a $\sigma^{70}$ subunit fragment from E. coli RNA polymerase. Cell 87: 127-136.

Mason, S.W., Li, J., and Greenblatt, J. 1992. Host factor requirements for processive antitermination of transcription and suppression of pausing by the $\mathrm{N}$ protein of bacteriophage $\lambda$. J. Biol. Chem. 267: 19418-19426.

Mogridge, J., Mah, T.F., and Greenblatt, J. 1995. A protein-RNA interaction network facilitates the template-independent cooperative assembly on RNA polymerase of a stable antitermination complex containing the $\lambda \mathrm{N}$ protein. Genes \& Dev. 9: 2831-2845.

Mogridge, J., Legault, P., Li, J., van Oene, M.D., Kay, L.E., and Greenblatt, J. 1998. Independent ligand-induced folding of the RNA-binding domain and two functionally distinct antitermination regions in the phage $\lambda \mathrm{N}$ protein. Mol. Cell 1: 265-275.

Nudler, E., Kashlev, M., Nikiforov, V., and Goldfarb, A. 1995. Coupling between transcription termination and RNA polymerase inchworming. Cell 81: 351-357.

Olson, E.R., Flamm, E.L., and Friedman, D.I. 1982. Analysis of nutR: A region of phage $\lambda$ required for antitermination of transcription. Cell 31: 61-70.

Olson, E.R., Tomich, C.S., and Friedman, D.I. 1984. The nusA recognition site. Alteration in its sequence or position relative to upstream translation interferes with the action of the $\mathrm{N}$ antitermination function of phage $\lambda$. J. Mol. Biol. 180: 1053 1063.

Richardson, J.P. and Greenblatt, J. 1996. Control of RNA chain elongation and termination. In Escherichia coli and Salmonella typhimurium (ed. F.C. Neidhardt), pp. 822-848. ASM Press, Washington, D.C.

Ringquist, S., Jones, T., Snyder, E.E., Gibson, T., Boni, I., and Gold, L. 1995. High-affinity RNA ligands to Escherichia coli ribosomes and ribosomal protein S1: Comparison of natural and unnatural binding sites. Biochemistry 34: 3640-3648.
Ross, W., Gosink, K.K., Salomon, J., Igarashi, K., Zou, C., Ishihama, A., Severinov, K., and Gourse, R.L. 1993. A third recognition element in bacterial promoters: DNA binding by the $\alpha$ subunit of RNA polymerase. Science 262: 1407-1413.

Salstrom, J.S. and Szybalski, W. 1978. Coliphage $\lambda$ nut $L^{-}$: A unique class of mutants defective in the site of gene $N$ product utilization for antitermination of leftward transcription. I. Mol. Biol. 124: 195-221.

Schauer, A.T., Cheng, S.W., Zheng, C., St. Pierre, L., Alessi, D., Hidayetoglu, D.L., Costantino, N., Court, D.L., and Friedman, D.I. 1996. The $\alpha$ subunit of RNA polymerase and transcription termination. Mol. Micro. 21: 839-851.

Schmidt, M.C. and Chamberlin, M.J. 1987. NusA protein of Escherichia coli is an efficient transcription termination factor for certain terminator sites. J. Mol. Biol. 195: 809-818.

Schuler, G.D., Altschul, S.F., and Lipman, D.J. 1991. A workbench for multiple alignment construction and analysis. Proteins 9: 180-190.

Schultz, J., Copley, R.R., Doerks, T., Ponting, C.P., and Bork, P. 2000. SMART: A web-based tool for the study of genetically mobile domains. Nucleic Acids Res. 28: 231-234.

Siomi, H., Matunis, M.J., Michael, W.M., and Dreyfuss, G. 1993. The pre-mRNA binding $\mathrm{K}$ protein contains a novel evolutionarily conserved motif. Nucleic Acids Res. 21: 1193-1198.

Subramanian, A.R. 1983. Structure and functions of ribosomal protein S1. Prog. Nucleic Acid Res. Mol. Biol. 28: 101-142.

Tang, H., Severinov, K., Goldfarb, A., and Ebright, R.H. 1995. Rapid RNA polymerase genetics: One-day, no-column preparation of reconstituted recombinant Escherichia coli RNA polymerase. Proc. Natl. Acad. Sci. 92: 4902-4906.

Tsugawa, A., Saito, M., Court, D.L., and Nakamura, Y. 1988. nusA amber mutation that causes temperature-sensitive growth of Escherichia coli. J. Bact. 170: 908-915.

Whalen, W., Ghosh, B., and Das, A. 1988. NusA protein is necessary and sufficient in vitro for phage $\lambda N$ gene product to suppress a $\rho$-independent terminator placed downstream of nutL. Proc. Natl. Acad. Sci. 85: 2494-2498.

Zheng, C. and Friedman, D.I. 1994. Reduced $\rho$-dependent transcription termination permits NusA-independent growth of Escherichia coli. Proc. Natl. Acad. Sci. 91: 7543-7547. 


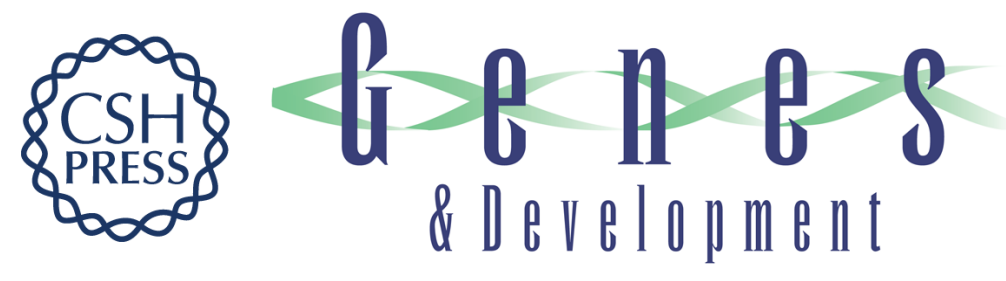

\section{The $\alpha$ subunit of $E$. coli RNA polymerase activates RNA binding by NusA}

Thien-Fah Mah, Konstantin Kuznedelov, Arcady Mushegian, et al.

Genes Dev. 2000, 14:

Access the most recent version at doi:10.1101/gad.822900

References This article cites 52 articles, 12 of which can be accessed free at: http://genesdev.cshlp.org/content/14/20/2664.full.html\#ref-list-1

License

Email Alerting

Receive free email alerts when new articles cite this article - sign up in the box at the top Service right corner of the article or click here.

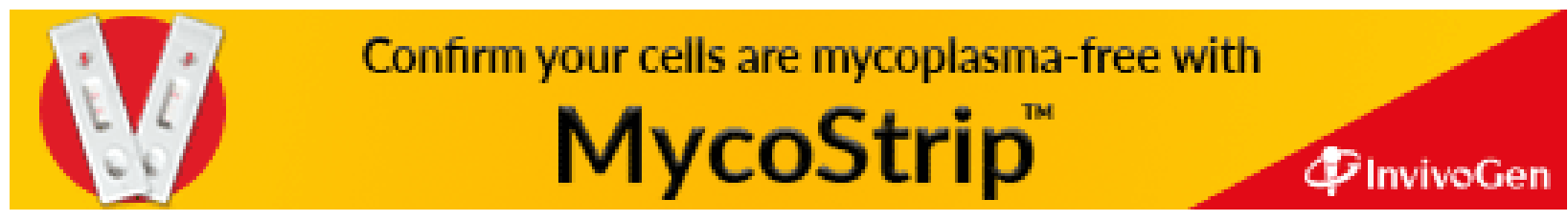

